\title{
Moving Towards Sustainable Development? Integrating Economic Development and the Environment in Local Authorities
}

\author{
DAVID GIBBS*, JAMES LONGHURST† \& CLARE BRAITHW AITE‡ \\ *School of Geography and Earth Resources, University of Hull, North Humberside HU6 7RX, \\ UK \\ tDepartment of Environmental Health and Science, University of the West of England, \\ Coldharbour Lane, Bristol BS16 1QY, UK \\ $\ddagger$ Department of Environmental and Geographical Sciences, Manchester Metropolitan \\ University, Chester Street, Manchester M1 5GD, UK
}

(Received October 1995; revised January 1996)

\begin{abstract}
The recent growth of interest in sustainable development has led to the incorporation of the concept into policy making at a variety of scales. In all cases particular em phasis is placed upon the local scale as the focus for the implementation of policy and initiatives and especially upon local authorities as the major contributor to this process. There has been little assessment, however, of the extent to which local authorities either can, or are, undertaking such initiatives. This paper examines: the potential role that local authorities can play in integrating economic development and the environment; the forms of response and initiatives that are currently in place, drawing upon survey evidence from urban local authorities in England and Wales; and some of the limits to local authority action.
\end{abstract}

\section{Introduction}

In recent years environmental issues have rapidly risen up both the political and business agendas. Public interest in such environmental issues has fluctuated since the initial upsurge of concern in the 1960s and 1970s, but a particular feature of the recent revival of interest in environmental matters is a new approach to reconciling environmental protection with economic development. In the past, the options were seen as constituting either the environment or economic development. More recently the adoption of sustainable development as a guiding principle has supposedly allowed movement away from this simple dichotomy towards a debate around the type of development that can take place. While defining sustainable development in operational terms has proved difficult, it has been rapidly embraced at all levels of policymaking from the international (UNCED, 1992) to the supra-national (Commission of the European Communities (CEC), 1992), national (HM Government, 1994) and local (Local Government Management Board (LGMB), 1993). In all cases a major emphasis has been placed upon the local scale as the most appropriate for the delivery of 
sustainable development policies and initiatives, with a particular stress upon local authorities as the major contributor to this process. The LGMB, for example, has argued that local authorities are ideally placed to formulate a multi-level corporate strategy for the sustainable management of the local environment (LGMB, 1992). In the United Kingdom, however, the "radical environmental activity undertaken by UK local authorities... is non-statutory and, in contrast to the situation in some other Member States, undertaken without financial support from central government" (European Union Expert Group on the Urban Environment, 1994, p. 37). Local authorities have responded to the challenges raised by these policy statements by developing their own environmental strategies and initiatives (Agyeman \& Evans, 1994). Much of this has revolved around traditional environmental issues, such as open space, and around planning issues (Healey \& Shaw, 1994). Rather less attention has been focused upon the interrelationship with economic development issues at the local scale. However, it can be argued that the relationship between economic development and the environment within a local area (or, indeed, at any spatial scale) is fundamental to whether any advance towards a more sustainable future can be achieved. In this paper the following issues are examined: the potential role that local authorities can play in integrating economic development and the environment; the forms of response and initiatives that are currently in place, drawing upon survey evidence from urban local authorities in England and Wales; and an outline of the limits to local authority action.

\section{The Local Authority Role in Integrating Economic Development and the Environment}

One pragmatic reason for examining the role that local authorities can play in implementing sustainable development is because much of the emphasis within policy statements is placed upon the local scale as the most relevant for action. While the most appropriate spatial scale for implementing sustainable development is a more contentious issue than this suggests, it is certainly correct that an important component of policy design and implementation will occur at the local level. ${ }^{1}$ Implementing the Agenda 21 principles agreed at the 1992 Earth Summit requires the active participation of local authorities and communities, notably through the Local Agenda 21 process whereby each local area should have an agreed sustainable development policy in place by the end of 1996 (UNCED, 1992). The European Union's Fifth Environmental Action Programme Towards Sustainability stresses the role of local authorities in integrating economic development with environmental protection and emphasizes the need to address environmental issues on a sectoral and regional basis to achieve the integrated development of the economy and the environment involving all sectors of industry, the local community and local authorities (CEC, 1992; Welford \& Gouldson, 1993). A number of key areas are identified within the Fifth Environmental Action Programme where local authorities have an important role, including spatial planning, economic development, infrastructure development, industrial pollution, waste management and transport (CEC, 1992). In the United Kingdom the initial emphasis provided by the government White Paper This Common Inheritance has been followed by the UK sustainable development strategy, as well as a number of planning guidance notes emphasizing the 
need for sustainable development to be incorporated into local planning practice for transport and physical development (HM Government, 1990, 1994).

One result of these policy initiatives has been a grow th of interest in examining the practical implications of sustainable development for local economies. Much of this activity has been galvanized by the Local Agenda 21 process and by international schemes such as the Canadian-based International Council for Local Environmental Initiatives' (ICLEI) Local Agenda 21 Communities Network to establish demonstration projects in local authority areas. In the United Kingdom a major role is being played by the LGMB, both in its own right as a co-ordinating body promoting $\mathrm{UN}$ and EU environmental policy and good practice (LGMB, 1993) and through the LGMB's work in co-ordinating the UK local authority associations' Local Agenda 21 Steering Group (Gibbs \& Healey, 1995). LGMB's work on greening economic development identifies five possible aims which can act as a basis for an integrated approach to environmental and economic strategies (LGMB, 1993):

- helping businesses to reduce their impacts on the environment;

- encouraging a move towards a more sustainable mix of businesses in the area, for example, through inward investment;

- fostering the development of environmental industries in the local area;

- protecting the environment in ways that do not threaten jobs;

- seeking business opportunities through environmental protection and enhancement.

A similar interest in the local scale has emerged in academic work on sustainable development. For example, Norgaard (1988) has argued that sustainability can be implemented most successfully at the regional scale. Other commentators place considerable emphasis upon the local scale as the most appropriate level for implementing sustainable development, not only for improving the local environment, but also as a means of attracting business to that area (Roberts, 1994; Welford, 1995).

This interest in incorporating environmental issues in to local economic development has developed at a time when major changes have occurred in the context for, and form of, local economic policy making in the United Kingdom. This has involved a shift in central government policy aw ay from regional policy towards urban aid and the creation of what has been termed 'central government localism' (Martin \& Townroe, 1992), and a shift from welfare-based policies to place-based competitiveness (Stewart, 1994). The key element in the growth of local authority economic policy making has been a restructuring of local-central state relations. UK central government initiatives have eroded the powers and level of control by local authorities over the local economy (Meyer, 1991). "Far from increasing the potential of localities to develop the necessary indigenous foundations for economic development, the policy modes utilised have increased their dependency on central government for economic development options" (Cheshire et al., 1992, p. 356). A number of features characterize this 'new localism': the rise of local authority place marketing strategies; the fragmentation of local governance; and the emergence of public-private partnerships (Clarke \& Stewart, 1994; Bovaird, 1994). Such developments are often categorized as indicating the rise of an entrepreneurial form of local governance with a greater reliance upon private sector-led efforts to develop local entrepreneurial potential (Eisenschitz \& Gough, 1993). Over time, central govern- 
Table 1. Principles to guide environmentally sustainable local development

\begin{tabular}{ll}
\hline Principles & Measures \\
\hline $\begin{array}{l}\text { Sustainable } \\
\text { development }\end{array}$ & $\begin{array}{l}\text { Maintain minimum environmental capital } \\
\text { stock } \\
\text { Take into account full environmental costs } \\
\text { of activities } \\
\text { Enable individuals to share in decision } \\
\text { making }\end{array}$ \\
& $\begin{array}{l}\text { Inter- and Intra-generational social justice } \\
\text { Policies to encourage diversification, } \\
\text { full employment and high level of } \\
\text { control over decision making }\end{array}$ \\
Self-sufficiency & $\begin{array}{l}\text { Minimize resource use, minimize transfers } \\
\text { of resources and movement of wastes }\end{array}$ \\
Territorial integration & $\begin{array}{l}\text { Local area as a unified space, } \\
\text { functional integration }\end{array}$ \\
\hline
\end{tabular}

Source: Adapted from Roberts (1995).

ment has shifted from effectively privatizing and centralizing local functions (such as through Urban Development Corporations and Training and Enterprise Councils) to encouraging the development of integrated action between the public sector, the private sector and the wider community through a partnership approach. Indeed, funding regimes such as City Challenge and the Single Regeneration Budget specifically emphasize the need for a partnership approach.

Some commentators have argued that these partnerships can be developed with the explicit aim of integrating economic development and the environment. Welford \& Gouldson (1993) stress the need for a Regional Environmental Management System which brings together individuals, business, the public sector and other agencies in partnerships which combine aspirations and objectives in a clear regional strategy. In their view this could provide regions with a comparative advantage which can be promoted through 'environmental labelling' of the region. Roberts (1994, p. 51) has argued that "area-based partnerships for the greening of industry and for the promotion of economic regeneration based upon the principles of sustainable development are... growing in importance and are likely to become dominant forces for change". More recently Roberts (1995), pointing to the antecedents of sustainable development in the balanced local and regional development approach of the Regional Planning Association of America in the 1920s, has argued that such partnerships can be developed most effectively at the local scale. Table 1 outlines the principles that Roberts (1995) suggests should guide local environmentally sustainable economic development. What is less clear is exactly how such principles can be implemented and it is this issue that local authorities are currently grappling with.

To address the issue, many local authorities have turned to devising and implementing their own strategies. Throughout the 1980 s local authorities increasingly produced environmental statements and strategies, although with 
varying degrees of commitment to subsequent action. However, an assessment of such local authority environmental statements and strategies concluded that few of them explicitly addressed economic development issues (Gibbs, 1993). Environmental strategies and economic development plans appeared to be generated from different perspectives-a reflection of their historic division and roots. The former largely evolved from environmental departments with an emphasis (often derived from their environmental health function) on protection, while the latter frequently developed out of planning functions. From the perspective of environment departments, business has historically been seen as a problem, the negative impacts of which need to be controlled and curbed. From a planning or economic development perspective, business is a source of wealth creation and employment generation which needs to be promoted and encouraged. If progress is to be made towards sustainability, the interrelationship between business and the environment is one which needs careful investigation. However, there is little empirical detail available of how, and where, initiatives which integrate the two are being introduced.

The research on which this paper is based is attempting to provide more detail of these initiatives and, in current work, the processes behind them. It is concerned with examining the extent to which local authorities are integrating economic development and the environment, with the form such initiatives are taking, with the internal structures associated with initiatives and with the barriers to policy implementation.

\section{Methodology}

The project comprises a programme of research to investigate how local authorities are addressing the issues of sustainable development and the environment in their economic development strategies and policies. It is especially concerned with the ways in which local authorities are attempting to integrate economic development strategies and initiatives with environmental aims and policies. A first stage of the research has been to conduct a postal survey of urban local authorities in England and Wales. These were defined as metropolitan boroughs, London boroughs, plus those non-metropolitan cities as defined in the 1991 Census Users' Guide. The survey was undertaken with the intention of:

- monitoring the progress of the integration of environmental aims and objectives into economic development policies;

- identifying current initiatives integrating economic development and the environment;

- identifying the outline structures within local authorities for implementing sustainable development policies;

- identifying 'most developed' or 'best practice' scenarios for further case study investigation.

A total of 96 urban local authorities were sent a postal questionnaire and 60 were returned (a response rate of $62.5 \%$, see Table 2 ).

Integrating Economic Development and the Environment: Survey Evidence Commitment to Sustainable Development

A set of questions sought to establish the extent to which local authorities are responding to sustainable development issues. As a basic measure, respondents 
Table 2. Survey response rate by local authority type

\begin{tabular}{lccc}
\hline Local authority type & Absolute no. & Response rate no. & $\%$ \\
\hline Lond on boroughs & 33 & 20 & 60.6 \\
Metropolitan boroughs & 36 & 20 & 55.6 \\
Non-metropolitan cities & 27 & 20 & 74.1 \\
Total & 96 & 60 & 62.5 \\
\hline
\end{tabular}

Source: Survey data.

were asked to indicate the documentation that had been produced on environmental and sustainable development issues. Figure 1 reveals that while most $(79 \%)$ had produced an environmental statement or charter, relatively few had produced more detailed documentation or studies which could establish a local environmental baseline against which the effectiveness of policies could be tested. Thus only $29 \%$ had undertaken an internal environmental audit assessing the local authority's own practices and just under a quarter (24\%) had undertaken a state of the environment (SoE) report. Only a similar proportion had produced a Local Agenda 21 plan $^{2}$ and only 16\% a strategy for sustainability (Figure 1).

Another set of survey questions attempted to reveal other broad indicators of local authority action. Thus only $41 \%$ of respondents had signed the UK Local Government Declaration on Sustainable Development organized through the LGMB (although 29\% of respondents did not know whether this had been signed). A larger proportion (48\%) either had, or planned to introduce, an internal environmental management system, such as BS7750 or the Eco-management and Audit Scheme (EMAS), although even here $16 \%$ of respondents did not know whether this had been undertaken.

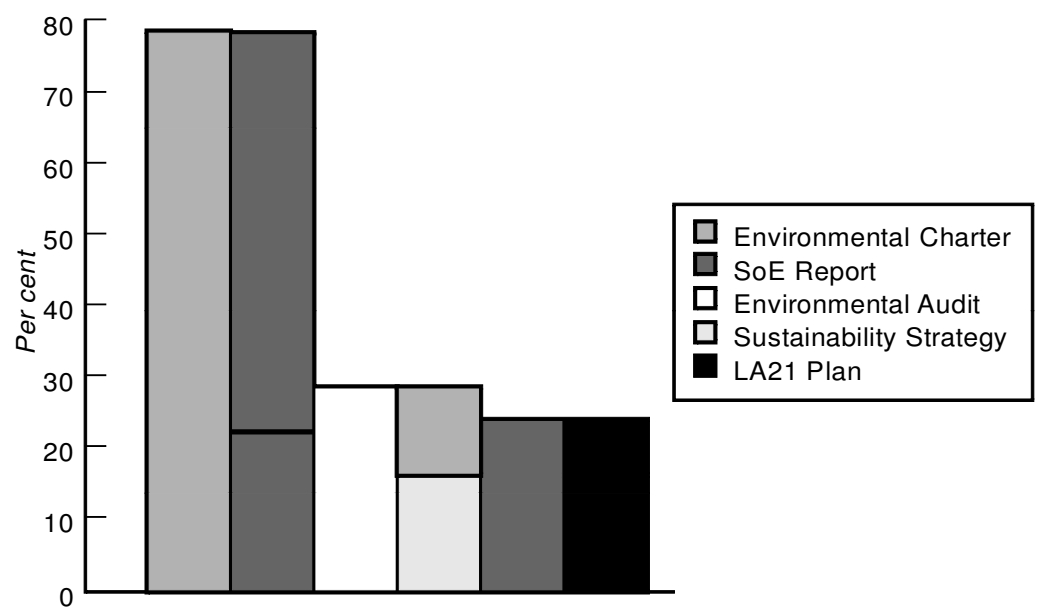

Figure 1. Proportion of local authorities with environmental documentation. Source: survey data. 
This evidence therefore suggests that the formal response to issues of sustainable development is relatively muted so far. However, $46 \%$ of local authorities stated that they had set targets and/or timescales for environmental improvements in their area. This may be a better indicator of a commitment to action. The extent to which local authorities are identifying indicators of limits and carrying capacities is of importance because it allows an evaluation of strategies and initiatives which are working and those which are not. Examples of these from the survey include: air quality monitoring and emissions reduction strategies; developing sustainability indicators; setting recycling targets; and setting targets for reducing internal energy use.

\section{Internal Organization}

In terms of organization, a large majority of local authorities (84\%) had an internal committee or sub-committee established to address issues of sustainable development. The survey evidence does not provide detail on the extent to which these are new committees, with a specific commitment to sustainable development, and which are simply old committees with new labels. The financial powers of such committees are limited, with only $25 \%$ having a separate budget to deal with sustainability or Local Agenda 21 issues. These internal committees had representation from four main departments: Planning; Environment; Chief Executive; and Economic Development. However, the dominance of planning and environment departments in dealing with sustainable development and Local Agenda 21 issues is shown by the fact that in $64 \%$ of local authorities, one or other of these departments is the lead department on the committee. In only $6 \%$ of cases was Economic Development the lead department, although a number of local authorities had joint initiatives (see Figure 2). This key role of planning departments in sustainable development within local authorities is confirmed by the work of Owens (1994) and Healey \& Shaw (1994).

While these internal committees are the preserve of officers and members, a number of local authorities $(40 \%)$ had also established bodies to encourage involvement by, and partnership with, the wider community. These typically took the form of an Environmental Forum or Local Agenda 21 working party. A major shortcoming of these bodies, from an economic development perspective, is that most had little or no business representation, except in a few isolated examples (such as in Manchester and Leeds). In addition to the local authority's own representatives, such bodies were mainly composed of pressure groups, community groups and residents' associations. This suggests that any privatepublic partnerships to integrate economic development and the environment currently lack the business involvement that is crucial to their success.

In order to illuminate the possible relationship between organizational structures and 'success' in integrating economic development and the environment, those local authorities with the most developed initiatives ${ }^{3}$ were identified and their organizational arrangements, as outlined in the survey responses, examined in more detail. Twelve such local authorities were identified: Kirklees; Southampton; Leeds; Leicester; Cardiff; Bradford; Croydon; Greenwich; Bristol; Reading; Middlesbrough; and Doncaster. ${ }^{4}$ A common feature of these authorities was that internal responsibility for sustainable development issues frequently 


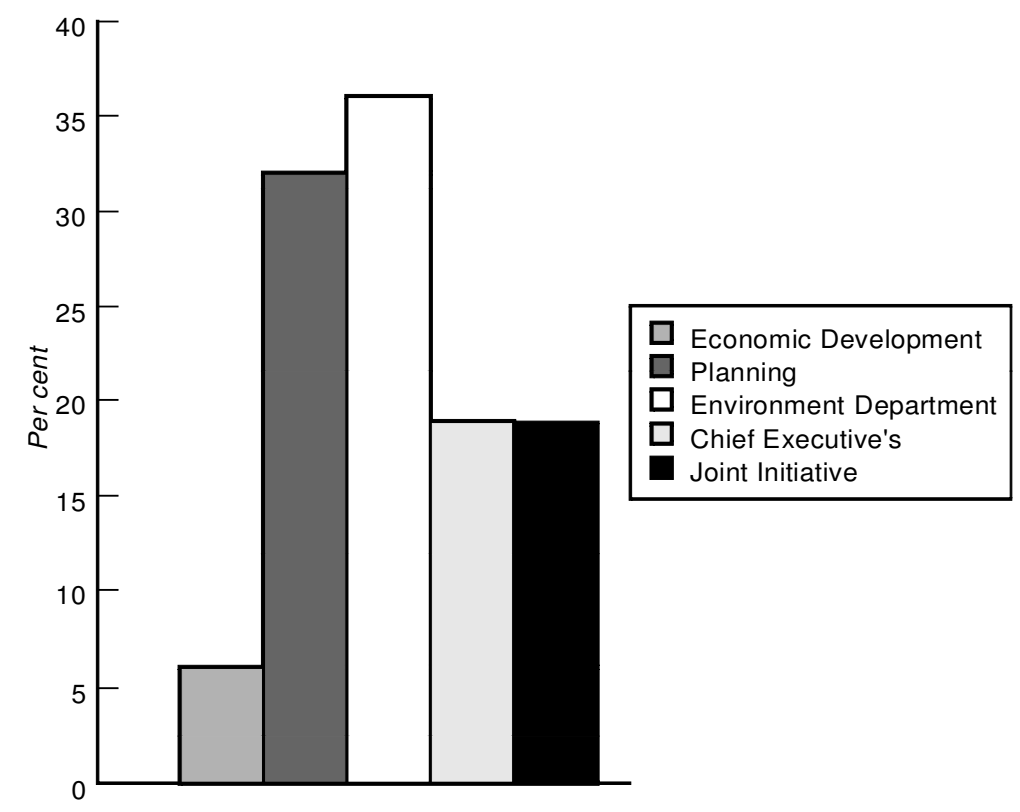

Figure 2. Lead departments dealing with sustainable development. Source: survey data.

rested with some form of cross-departmental committee, sub-committee or working group. In six of the 12 there was not only an internal group of officers and/or members with responsibilities for sustainable development, but also a broader environmental forum-type organization. Most of these latter bodies had representation from all, or most, of the local authorities' departments, although the lead department was frequently an environmental one. The broader forumtype bodies were thus more likely to have a wider intra-local authority representation, as well as representation from outside groups or individuals, including business.

\section{Economic Development Policy and the Environment}

In an attempt to discover the extent to which existing policies seek to integrate economic development with environmental and/or sustainable development policies, respondents were asked a series of questions to indicate where integration is taking place. Figure 3 reveals that while $71 \%$ of Unitary Development or Local Plans are said to contain integrative policies, only $47 \%$ of Economic Development Plans do so. Just under half the respondents $(44 \%)$ undertake any environmental evaluation of their economic development policies. Even here, however, the means of doing so tended to lack any formal mechanism, with $48 \%$ using the existing planning appraisal process by reference to the Local Plan, and a further $20 \%$ who said they used 'personal judgement' without specifying the process. Few used the Department of the Environment's 'good practice' 


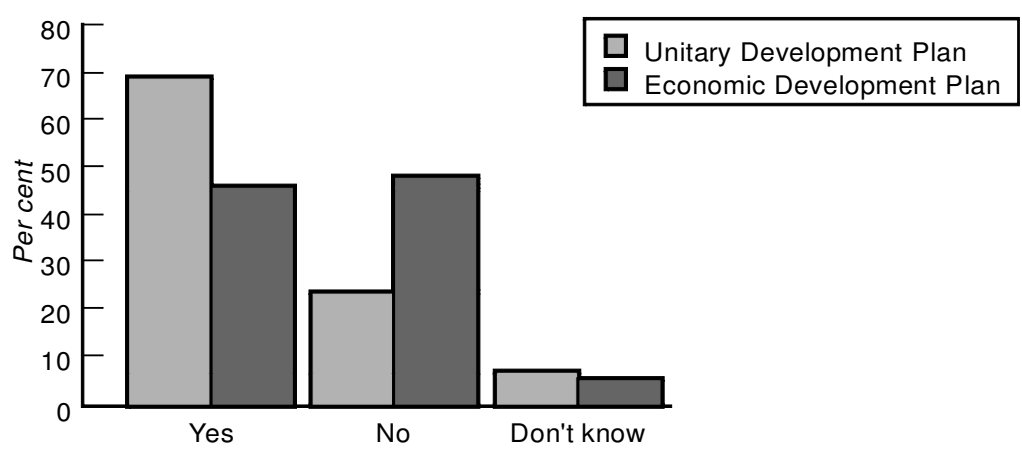

Figure 3. Integration of environmental and economic policies. Source: survey data.

appraisal guide (Department of the Environment, 1993) or any form of environmental impact assessment.

In assessing how important environmental issues are in terms of economic development policy objectives, respondents were asked to rank a number of factors on a scale of 1-10. In terms of factors ranked as 'most important', creating/keeping employment predominated, followed by protecting the environment, encouraging inward investment and a good transport infrastructure. While this may seem encouraging, if all factors are ranked by their overall aggregate score then protecting the environment comes much further down the list (see Table 3). In overall terms environmental issues are not ranked particularly highly in terms of policy objectives. Some respondents found it difficult to rank these factors, a typical comment being, "all these are important as part of an integrated strategy of mutually supporting elements, which cannot meaningfully be ranked as separate projects". The intention was, however, to at least attempt a crude assessment of the importance of environmental issues within economic development policies.

Table 3. Aggregate rank order of economic development policy objectives

\begin{tabular}{ll}
\hline Rank order & Policy objective \\
\hline 1 & Creating/keeping em ployment \\
2 & Encouraging inward investment \\
3 & Encouraging new / small firms \\
4 & Costs/availability of land and property \\
5 & Good transport infrastructure \\
6 & Costs/availability of labour \\
7 & Image of the area \\
8 & Protecting the environment \\
9 & Community development \\
10 & Other factors (included housing, city \\
& centre regeneration, promoting new \\
& technology and sectoral development) \\
\hline
\end{tabular}




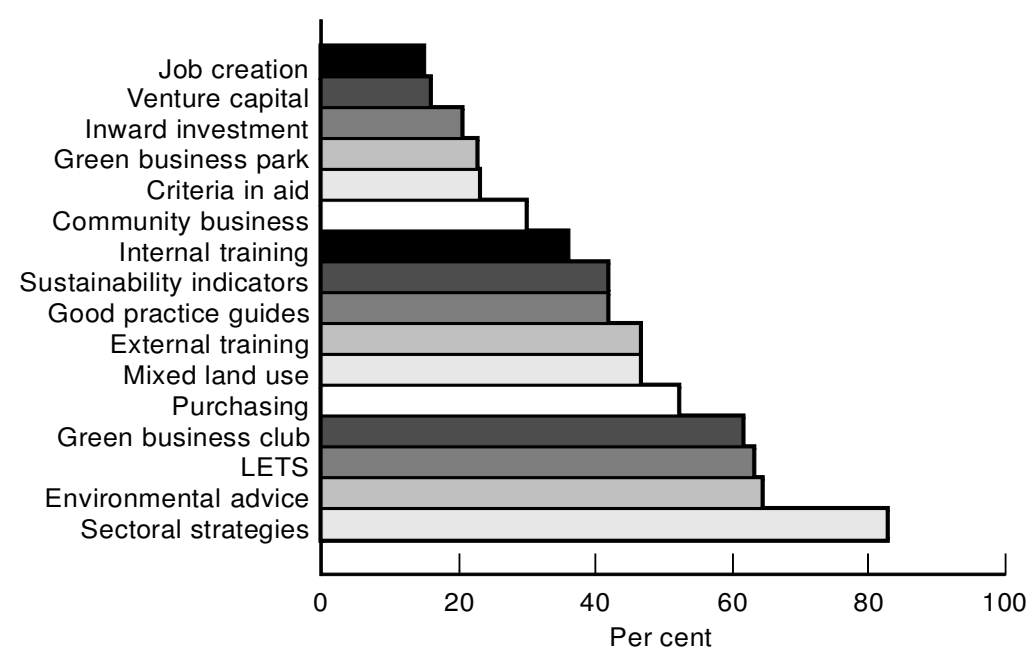

Figure 4. Types of local authority initiatives linking economic development and the environment. Source: survey data.

\section{Economic Development Initiatives and the Environment}

Despite the relatively limited importance of the environment as a policy objective, a large proportion of local authorities have initiatives in place, or planned, which seek to integrate economic development and the environment. These are shown in Figure 4. The main initiatives are: sectoral strategies (for example, towards environmental technology firms) providing environmental advice to firms; establishing Local Exchange Trading Systems (LETS); 'green business clubs'; and developing an internal purchasing strategy linked to environmental initiatives. While this may appear to indicate a high level of activity, case study evidence is beginning to reveal that many of these initiatives are small scale and in their early stages.

The majority of local authorities (61\%) had received, or applied for, external funding to help develop these initiatives. Funding from the European Commission was particularly important. All local authorities in receipt of, or having applied for, funding had done so to the Commission. UK central government funding applications had been made by $61 \%$. There were very few instances of initiatives which involved funding or partnership arrangements $w$ ith the private sector. Nearly a third of respondents $(30 \%)$ were engaged in initiatives with other local authorities, mostly in the UK with a few involved in overseas projects. These included joint schemes with adjacent local authorities (often with other district authorities or county councils) and through European networks. Nearly half $(44 \%)$ of respondents were able to identify other initiatives in their area which do not have local authority involvement (although 25\% did not know). Table 4 indicates that these fell into three main categories. The majority of initiatives either provide assistance to, or work with business, or are part of regeneration schemes, usually involving the clean up of contaminated land or general environmental improvement. A small number of initiatives were 
Table 4. Initiatives to integrate economic development and the environment

\begin{tabular}{ll} 
Type of initiative & Examples \\
\hline Business advice/assistance & $\begin{array}{l}\text { Leeds Business Environment Forum } \\
\text { ENVIRON, Leicester } \\
\text { Cardiff Environment Forum }\end{array}$ \\
$\begin{array}{l}\text { Regeneration and } \\
\text { environmental improvement }\end{array}$ & $\begin{array}{l}\text { Kegeneration } \\
\text { Hammersmith, Park Royal Partnership } \\
\text { Groundwork Trust, Birmingham }\end{array}$ \\
& Miles Platting/Ancoats, environmental job creation \\
Knowsley, furniture recycling community enterprise \\
Greenwich, recycling electrical appliances
\end{tabular}

Source: Survey data.

community-based, where job or business creation was being linked to the environment.

\section{Obstacles to Integrating Economic Development and the Environment}

Finally, respondents were asked what they saw as the major obstacles within their local authority to implementing or furthering initiatives which try to integrate economic development and the environment. Of those factors listed as most important, lack of finance was the dominant reason, followed by the fact that other priorities, such as jobs and firm closures, were deemed to be of more importance.

More detailed evidence on the problems that occur was provided by responses to a final open question in the survey. For example, one respondent from a London Borough stated that, "members still view these issues in terms of a straight trade-off between jobs and the environment", while another stated that, "there is a little scepticism amongst our members about the ability of a local authority to influence economic development/environmental issues". Another respondent commented that while sustainable development issues are seen as important within the department, the resources devoted to them often suffer vis-à-vis more 'front-line' economic development issues. Another comment from a London borough was that:

...confidentially...there is so little appreciation and understanding of environmental issues and what their incorporation requires or could mean, that all I can say is that we have a very long way to go. It only happens (or rather is mentioned) when doing so is a requirement for getting money, e.g. European or Department of the Environment grants or budgets, and making 'caring for the environment' statements in corporate plans.

Indeed, many respondents seemed isolated in their views within their own local authority and there were pleas for more advice and specific guidance to help them with these issues. 
On a more positive note, several comments emphasized that sustainable development issues had only recently been taken seriously by the local authority and that a higher level of activity could be expected in the near future. This is summed up by one respondent who stated, "our Borough Plan and Economic Development Strategy were both drafted some time before sustainability emerged as an issue anyone could understand. They both address sustainability, but not in an overly integrated fashion". The more narrow view of the environment that has prevailed to date is revealed in a comment from a borough in North West England: “we have environmental improvement strategies-greening the borough-but we haven't got to grips with the sustainability argument".

\section{Conclusions: The Limits to Local Authority Action}

The survey evidence reveals an overall picture of limited attempts by local authorities in England and Wales to integrate economic development and the environment. Policy prescriptions may emphasize the local scale as the relevant level for action, but sustainable development or environmental issues appear to be a relatively unimportant concern for local authority-led economic development policy. A theme which does emerge is the dominant role of planning and environmental departments, as opposed to economic development departments, in taking forward the sustainable development agenda in local authorities. This may help to explain the incorporation of integrative strategies in Unitary and Local Development Plans and their relative absence from Economic Development Plans. Despite their absence from policy, a high proportion of local authorities do have, or plan to have, integrative initiatives in place such as sectoral strategies, environmental advice to business, LETS schemes and green business clubs. From the survey evidence it is not possible to estimate the scale or importance of such initiatives, especially compared to other economic development initiatives in place. Nor is it possible to determine the effectiveness of such initiatives, although the lack of targets set and environmental assessment procedures in place may suggest that local authorities will have problems in assessing this themselves. There is also little evidence, at least from a local authority perspective, of widespread externally-led integrative initiatives. These were present in nearly half of local authority areas, but were dominated by business advice schemes and fairly conventional environmental improvement or regeneration schemes. There were few schemes which involved the types of area-based partnerships advocated by Roberts (1995) or Welford \& Gouldson (1993) and even those committees and fora in place have little involvement from outside bodies or individuals, particularly from business. In total then, schemes which link together economic development and the environment are still in their infancy. No local authority initiatives come anywhere near fitting the principles for environmentally sustainable economic development outlined in Table 1. While respondents to the survey revealed a high level of awareness of the issues through their comments, many seemed to be the 'lone voice' trying to convince other economic development officers and members that going beyond environmental improvements to the physical environment, such as clearing derelict or contaminated land, is not simply a choice between jobs and the environment.

The evidence outlined in this paper indicates that the implementation of sustainable development by local authorities in England and Wales currently falls far short of the policy prescriptions made for local level action. Nevertheless 
it could be argued that this simply represents the start of what will be a lengthy process of adjustment and experimentation with an ill-defined concept. In this final section of the paper, some of the limits to such future actions at the local level are explored and the need for a local scale approach reiterated.

First, it is important to recognize that there are obvious limits to a local authority's influence on private business and individual behaviour, compounded by central government placing limits upon a local authority's ability to restrain 'unsustainable' activities and decisions in the private sector, for example, by prohibiting the use of the planning system to prevent polluting activities, and through the growth in 'central government localism' (Thomas, 1994). Indeed, a much broader question than can be dealt with here is the extent to which business can be redirected onto a course of ecologically sustainable development. At present, "the idea of an ecological capitalism, or a sustainable capitalism, has not even been coherently theorised, not to speak of becoming embodied in an institutional infrastructure" (O'Connor, 1994, p. 168). It is thus premature to expect it to be delivered through local authority action! Indeed, the real challenge of sustainable development comes not simply through developing appropriate policies and initiatives that can be introduced at the local scale, it is also "a political challenge for real leverage over economic discourse" (Healey \& Shaw, 1994, p. 434). Sustainable development then is a fundamentally political concept and, "its realisation lies in answers to such questions as who is in control, who sets agendas, who allocates resources, who mediates disputes, who sets the rules of the game" (Wilbanks, 1994, p. 544). In this respect, then, the scale of the challenge to current political economy represented by sustainable development policies is barely recognized (Owens, 1994). The challenge may necessitate more radical measures than either local or national governments envisage. The survey evidence suggests that local authorities themselves still see conflicts between environmental protection and economic development. Creating and keeping jobs are ranked higher than environmental protection and members remain to be convinced that the two areas are compatible. There is, therefore, a need to develop genuinely integrative policies and initiatives across the range of policy spheres. This is an area which requires further research and where recent work on ecological modernization may be of assistance. This body of work suggests that stringent environmental policy can act to improve economic efficiency and technological innovation at the same time that economic entrepreneurship can have environmental advantages, such as through the development of clean technologies (Simonis, 1993; Spaargaren \& Mol, 1991).

Second, much of the emphasis in the literature on developing integrative strategies relies upon redirecting economic development onto this course by means of co-operation and consensus within a local area between the local authority, the business sector and the local community. However, there are substantial tensions over the different visions and expectations that different groups of people have over the same place. ${ }^{5}$ Local government is being expected to act as a mediator between competing interests in these conflicts (overtly in the case of Local Agenda 21) and the business and environment interface is a key area where these tensions are amongst the most acute (Marsden et al., 1993). The survey evidence reveals the limited participation by the private sector in local initiatives to integrate the environment and economic development. While partnership may be an important part of the rhetoric of local economic development, there is little evidence of its existence in such integrative initiatives. Where 
the private sector is involved in initiatives, these are fairly conventional land reclamation or business advice schemes.

Third, there is the question of the appropriate scale for action to implement policies for sustainable development. On the one hand, local action may improve environmental conditions within an area, providing an example to others and at least initiating a move away from unsustainable practices. On the other hand, this ignores the interconnections between areas in terms of flows of goods and pollutants. Can an area only become 'green' through externalizing its own environmental impacts and ignoring its 'environmental footprint' elsewhere? Does a 'solution' at the scale of one locality simply mean displacing the problem elsewhere? (Dryzek, 1994). At a global scale there is a major contradiction between a vision of the future based upon international trade and comparative advantage (White \& Whitney, 1992) and a vision of the future based upon local self-sufficiency (see Table 1).

As Stren (1992, p. 313) states:

a practical difficulty with implementing an environmental agenda relates to what might be called the jurisdictional ambivalence of environmentalism. This ambivalence is reflected vertically (in terms of levels of government and administrative systems) in the concern of environmentalists for regional, national, and even international solutions to many problems, at the same time as the most active focus of much environmental, political activity is the local community or even the household.

While the nature of the important environmental problems is global in scale, implementing policy at this level is problematic. Conversely, individual local areas are too small to cope with environmental problems that stretch across administrative boundaries. However, individual local authorities acting in isolation, as with individual firms or countries acting in isolation, will not 'solve' environmental problems because of their cross-boundary nature. Approaching sustainable development from the purely local level is not enough. What is needed is an interplay between policy 'from above' (for example, Agenda 21 and EU policy) and 'from below'. In the UK the implementation of such an interplay is hindered by the lack of a regional tier of government. The lack of this tier of government makes the construction of local policies more difficult in the absence of regional policies and means that local policies lack economies of scale. In the case of those UK regions which are eligible for European Union Structural Funds this has been addressed, to some extent, through the required preparation of regional development strategies and the production of Single Programming Documents (SPDs) which identify regional problems and devise coherent regional programmes to address them, including an appraisal of the environmental situation. The survey evidence may indicate that local authorities themselves realize the importance of a broader spatial perspective given the evidence of several joint schemes with adjacent local authorities.

As Keil (1995, p. 290) points out:

activating the 'local' is now considered a necessary, though not sufficient, condition by environmental policy-makers. It is necessary because strategies to solve environmental problems, in order to be successful, need to be broken down to the experiential base of the local... The local, 
however, is also not a sufficient condition for environmental policymakers because environmental action can by no means be just local, it needs to be supplemented by regional initiatives... and...to be synchronised with global and transnational activities of environmental advocacy and policy making.

The issue of the appropriate scale is therefore one which need s more attention. The complex relationships between economy, environment and society that exist globally can usefully be unpacked by careful local research (Wilbanks, 1994); but it is also true that while putative solutions need to be developed at the local scale, these must be intermeshed with a national and international framework (Peck \& Tickell, 1994; Roberts, 1995). Even so, despite the fact that these broader frameworks are needed, rather than endlessly speculating about grandiose, sweeping structural transformations, it seems sensible to evaluate simultaneously the possibilities of implementing a succession of small, and in themselves insufficient, actions that cumulatively can contribute to the resolution of problems (Dryzek, 1994; Roberts, 1995).

\section{Acknowledgements}

The research on which this paper is based is funded through the ESRC's Global Environmental Change programme (Grant no. L320252132). We would like to thank two anonymous referees for their advice on improving the content and clarity of the paper.

\section{Notes}

1. The issue of appropriate spatial scale is one that is returned to in the conclusions to this paper.

2. Perhaps a relatively high proportion given that the timescale for producing Local Agenda 21 statements is not until the end of 1996. Several handwritten comments on the questionnaires suggested that few have a final plan as yet, most are better described as 'work-in-progress'.

3. This was essentially a subjective assessment of local authorities based upon the number of initiatives which sought to integrate economic development and the environment in operation at the time of the survey.

4. Guarantees of confidentiality do not allow the details to be explored in any depth in this paper. Case study work is proceeding with some of these authorities.

5. Peck \& Tickell (1995) outline the lack of consensus even within the business sector over economic development strategies within a region.

\section{References}

Agyeman, J. \& Evans, B. (1994) Local Environmental Policies and Strategies (London, Longman).

Bovaird, T. (1994) Managing urban economic development: learning to change or the marketing of failure?, Urban Studies, 31(4/5), pp. 573-603.

Cheshire, P.C., D’Arcy, E. \& Giussani, B. (1992) Purpose built for failure? Local, regional and national government in Britain, Environment \& Planning C: Government \& Policy, 10, pp. 355-369.

Clarke, M. \& Stewart, J. (1994) The local authority and the new community governance, Regional Studies, 28(2), pp. 201-207.

Commission of the European Communities (1992) 'Towards sustainability'-European Union programme of policy and action in relation to the environment and sustainable development, COM 92(23) (Brussels, CEC).

Department of the Environment (1993) The Environmental Appraisal of Development Plans: A Good Practice Guide (London, HMSO).

Dryzek, J. (1994) Ecology and discursive democracy: beyond liberal capitalism and the administrat- 
ive state, in: M. O'Connor (Ed) Is Capitalism Sustainable? Political Economy and the Politics of Ecology (New York, Guilford Press).

Eisenschitz, A. \& Gough, J. (1993) The Politics of Local Economic Policy (London, Macmillan).

European Union Expert Group on the Urban Environment (1994) European Sustainable Cities, First Report, Sustainable Cities Project, XI/822/94-EN (Brussels).

Gibbs, D.C. (1993) The Green Local Economy (Manchester, Centre for Local Economic Strategies).

Gibbs, D.C. \& Healey, M.J. (1995) Local government, environmental policy and economic development, in: M. Taylor (Ed) Environmental Change: Industry, Power and Policy (Aldershot, Avebury), pp. 151-167.

HM Government (1990) This Common Inheritance, Cm 1200 (London, HMSO).

HM Government (1994) Sustainable Development, Cm 2426 (London, HMSO).

Healey, P. \& Shaw, T. (1994) Changing meanings of 'environment' in the British planning system, Transactions of the Institute of British Geographers, 19, pp. 425-438.

Keil, R. (1995) The environmental problematic in world cities, in: P. Knox \& P. Taylor (Eds) World Cities in a World System (Cambridge, Cambridge University Press), pp. 280-297.

Local Government Management Board (1992) Agenda 21: A Guide for Local Authorities in the UK (Luton, LGMB).

Local Government Management Board (1993) Greening Economic Development (Luton, LGMB).

Marsden, T., Murdoch, J., Lowe, P., Munton, R. \& Flynn, A. (1993) Constructing the Countryside (London, UCL Press).

Martin, R. \& Townroe, P. (1992) Changing trends and pressures in regional development, in: P. Townroe \& R. Martin (Eds) Regional Developmentin the 1990s: The British Isles in Transition (London, Jessica Kingsley/Regional Studies Association).

Meyer, P. (1991) Meaning and action in local economic development strategies: a comparison of policies in Britain and the United States, Environment $\mathcal{E}$ Planning C: Government E Policy, 9(4), pp. 383-398.

Norgaard, R. (1988) Sustainable development: a co-evolutionary approach, Futures, December, pp. 606-620.

O'Connor, J. (1994) Is sustainable capitalism possible? in: M. O'Connor (Ed) Is Capitalism Sustainable? Political Economy and the Politics of Ecology (New York, Guilford Press), pp. 152-175.

Owens, S. (1994) Land, limits and sustainability: a conceptual framework and some dilemmas for the planning system, Transactions of the Institute of British Geographers, 19, pp. 439-456.

Peck, J. \& Tickell, A. (1994) Jungle law breaks out: neoliberalism and global-local disorder, Area, 26(4), pp. 317-326.

Peck, J. \& Tickell, A. (1995) Business goes local: dissecting the 'business agenda' in Manchester, International Journal of Urban and Regional Research, 19(1), pp. 55-78.

Roberts, P. (1994) Environmental sustainability and business: recognising the problem and taking positive action, in: C.C. Williams \& G. Haughton (Eds) Perspectives Towards Sustainable Environmental Development (Aldershot, Avebury), pp. 37-53.

Roberts, P. (1995) Environmentally Sustainable Business: A Local and Regional Perspective (London, Paul Chapman).

Simonis, U. (1993) Industrial restructuring: does it have to be jobs vs. trees? Work in Progress of the United Nations University, 14(2), p. 6.

Spaargaren, G. \& Mol, A. (1991) Sociology, Environment and Modernity: Ecological Modernisation as a Theory of Social Change (Wageningen, LUW).

Stewart, M. (1994) Between Whitehall and town hall: the realignment of urban regeneration policy in England, Policy and Politics, 22(2), pp. 133-145.

Stren, R. (1992) Conclusion, in: R. Stren, R. White \& J. Whitney (Eds) Sustainable Cities: Urbanisation and the Environment in International Perspective (Boulder, CO, Westview), pp. 307-315.

Thomas, K. (1994) Planning for sustainable development: an exploration of the potential role of town planners and the planning system, in: C.C. Williams \& G. Haughton (Eds) Perspectives Towards Sustainable Environmental Development (Aldershot, Avebury), pp. 145-162.

UNCED (1992) Agenda 21 (Conches, Switzerland, UNCED).

Welford, R. (1995) Environmental Strategy and Sustainable Development (Lond on, Routledge).

Welford, R. \& Gouldson, A. (1993) EnvironmentalManagementand Business Strategy (London, Pitman).

White, R. \& Whitney, J. (1992) Cities and the environment, in: R. Stren, R. White \& J. Whitney (Eds) Sustainable Cities: Urbanization and the Environment in International Perspective (Boulder, CO, Westview), pp. 8-51.

Wilbanks, T.J. (1994) 'Sustainable development' in geographical perspective, Annals of the Association of American Geographers, 84(4), pp. 541-556. 